DOI: $10.6060 / \mathrm{mhc} 1711491$

\title{
UV-Vis Spectra and Aggregation of Hybrid Binuclear Lacunar Complexes
}

\author{
Oleg V. Gradov, ${ }^{\mathrm{a}, \mathrm{b}}$ Margaret A. Gradova, ${ }^{\mathrm{a}}$ Semyon V. Dudkin, ${ }^{\mathrm{c}}$ Yan Z. Voloshin, ${ }^{\mathrm{c}, \mathrm{d}}$ \\ and Anton V. Lobanova,e@ \\ Dedicated to Academician Aslan Yu. Tsivadze on the ocassion of his 75th Birthday \\ ${ }^{a} N . N$. Semenov Institute of Chemical Physics of Russian Academy of Sciences, 119991 Moscow, Russia \\ ${ }^{\mathrm{b}}$ V.L. Talrose Institute for Energy Problems of Chemical Physics of Russian Academy of Sciences, 119334 Moscow, Russia \\ 'A.N. Nesmeyanov Institute of Organoelement Compounds of Russian Academy of Sciences, 119991 Moscow, Russia \\ ${ }^{\mathrm{d} N}$.S. Kurnakov Institute of General and Inorganic Chemistry of Russian Academy of Sciences, 119991 Moscow, Russia \\ ${ }^{\mathrm{e}}$ G.V. Plekhanov Russian University of Economics, 117997 Moscow, Russia \\ ${ }^{\circledR}$ Corresponding authorE-mail: avlobanov@mail.ru
}

Four hybrid binuclear metal phthalocyaninate-capped iron(II) and nickel(II) tris-pyridineoximates have been studied both in solutions and the fuoroplastic thin films by UV-Vis absorption technique. The studied polymer-immobilized cage metal complexes form the H-type dimers within the polymer matrix.

Keywords: Macrocycles, zirconium phthalocyanine, hafnium phthalocyanine, iron complexes, nickel complexes, aggregation.

\section{Электронные спектры и агрегация гибридных биядерных лакунарных комплексов}

\author{
О. В. Градов, ${ }_{1}^{\text {a,b }}$ M. А. Градова, ${ }^{a}$ C. В. Аудкин, ${ }^{\text {c }}$ Я. З. Волошин, ${ }^{c, d}$ A. В. Лобанов ${ }^{a, e @ ~}$ \\ ${ }^{\mathrm{a}}$ ФБУУН Институт химической физики им. Н.Н. Семенова РАН, 119991 Москва, Россия \\ ${ }^{\mathrm{b}}$ ФББУН Институт энергетических проблем химической физики им. В.Л. Тальрозе РАН, 119334 Москва, Россия \\ 'ФГБУН Институт элементорганических соединений им. А.Н. Несмеянова РАН, 119991 Москва, Россия \\ ${ }^{\mathrm{d}}$ ФБУН Институт общей и неорганической химии им. Н.С. Курнакова РАН, 119991 Москва, Россия \\ ${ }^{\mathrm{e}}$ ФБОУ ВО Российский экономический университет им. Г.В. Плеханова, 117997 Москва, Россия \\ @E-mail: avlobanov@mail.ru
}

Методом электронной спектроскопии охарактеризованы четыре гибридных биядерньх комплекса триспиридиноксиматов железа(II) и никеля(II) с металлофталоцианинами в растворах и тонких фторопластовых пленках. Показано, что в полимерной матрице исследованные металлокомплексы образуют димеры Н-типа.

Ключевые слова: Макроциклы, циркониевый фталоцианин, гафниевый фталоцианин, комплексы железа, комплексы никеля, агрегация. 
Hybrid molecular systems based on the functionalized tetrapyrrolic compounds are intensively studied during last decade due to their emergent and attractive physicochemical properties caused by intramolecular interactions between their electronically coupled fragments. Nowadays, three main strategies of designing and preparation of hybrid molecular systems have been developed. They include: $(i)$ the direct covalent modification of the tetrapyrrolic macrocycle, ${ }^{[1]}$ (ii) supramolecular self-assembly of the pre-organized building blocks ${ }^{[2]}$ as well as (iii) the modern approaches of the coordination chemistry. ${ }^{[3]}$ The latter pathway has been used recently to obtain of the hybrid binuclear metal phthalocyaninate-capped tris-pyridineoximates, the molecules of which combine the optical and chemical properties of their macro(bi)cyclic precursors, tetrapyrrolic chromophores and main transition metal clathrochelates. [4-7] Such hybrid coordination compounds with relatively independent $\pi$ - and $\sigma$-electronic systems can be considered as promising components of molecular platform and scaffold of smart materials for molecular electronics, photovoltaic devices and single-molecular magnets. ${ }^{[8]}$

In this paper we are report the UV-Vis spectral characterization of four hybrid binuclear metal phthalocyaninatecapped tris-pyridineoximates (Figure 1a) and their aggrega-

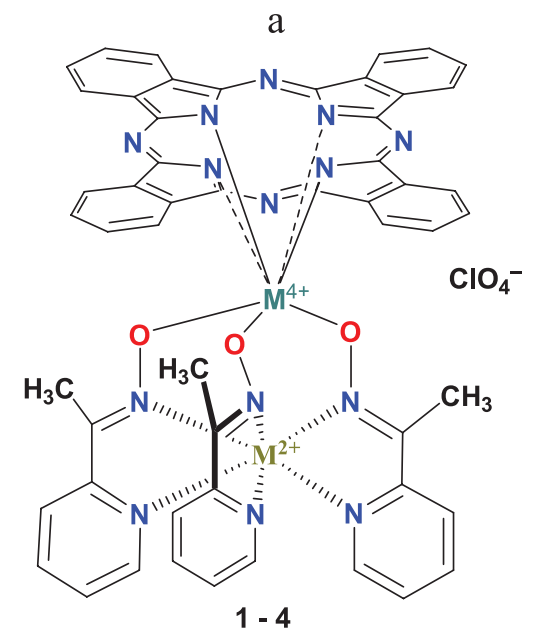

$$
\begin{array}{ll}
\text { 1: } M^{2+}=\mathrm{Fe}, \mathrm{M}^{4+}=\mathrm{Zr} & \text { 3: } \mathrm{M}^{2+}=\mathrm{Ni}, \mathrm{M}^{4+}=\mathrm{Zr} \\
\text { 2: } \mathrm{M}^{2+}=\mathrm{Fe}, \mathrm{M}^{4+}=\mathrm{Hf} & \text { 4: } \mathrm{M}^{2+}=\mathrm{Ni}, \mathrm{M}^{4+}=\mathrm{Hf}
\end{array}
$$

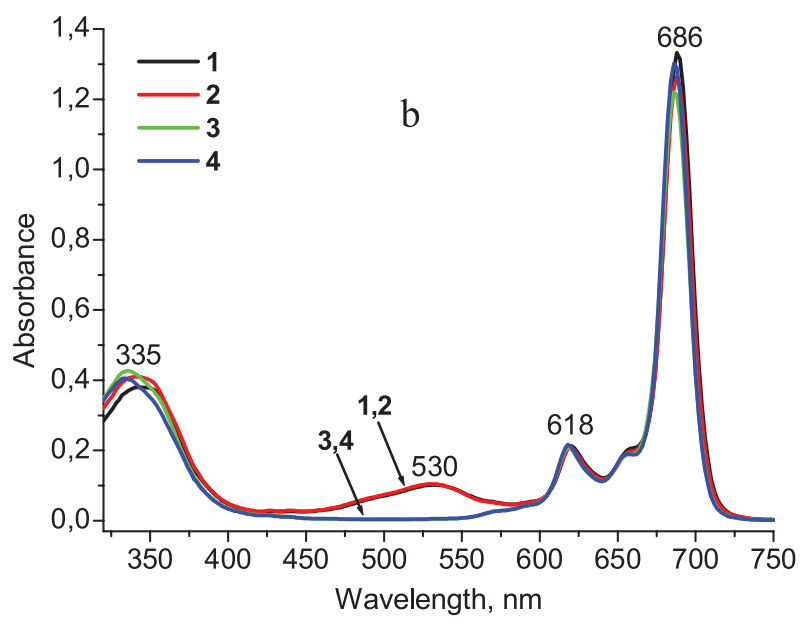

Figure 1. Chemical structure of the metal complexes 1-4 (a) and their UV-Vis spectra in DMF (b). tion in various media. Metal(II)-hafnium(IV)- and metal(II)zirconium(IV)-binuclear complexes with apical macroheterocyclic-capping fragment have been obtained by transmetallation of mono(triethylantimony)-capped iron(II) and nickel(II) tris-pyridineoximates with zirconium(IV) or hafnium(IV) phthalocyaninates as Lewis acids under mild reaction conditions. ${ }^{[9]}$

The UV-Vis spectra of the above hybrid complexes (Figure 1b) and the initial zirconium and hafnium(IV) phthalocyaninates $\left(\mathrm{M}\left(\mathrm{Cl}_{2}\right) \mathrm{Pc}\right)$ in DMF solution are rather similar in the most intensive fragments bands which assigned $\pi \rightarrow \pi^{*}$ transitions in the single tetrapyrrolic ligand $\left(\lambda_{B}=335-340 \mathrm{~nm}\right.$, $\left.\lambda_{\mathrm{Q}}=686 \mathrm{~nm}, \Delta v_{1 / 2}=465 \mathrm{~cm}^{-1}\right)$. A low-intense broad band near $530 \mathrm{~nm}$ in the spectra of iron(II)-centerd binuclear complexes $(\mathbf{1}, \mathbf{2})$ assigned as the metal-to-ligand charge transfer $\left(\mathrm{Fe} d \rightarrow \mathrm{L} \pi^{*}\right)$ band. The additive character of the above spectra, which are practically suggest the superposition bands of their precursors for both components reveals weak interactions between their Pc $\pi$-electronic system and that of the pseudomacrobicyclic metal(II)-centered fragment. A 10-nm bathochromic shift of the MPcs absorption bands upon formation of the hybrid complex can be explained by small distortion of this macroheterocycle.

Despite an unsufficient effect of such covalent hybridization on the UV-Vis spectra of 1-4, their fluorescence is completely quenched as compared to the parent $\mathrm{Zr}\left(\mathrm{Cl}_{2}\right) \mathrm{Pc}$ $\left(\lambda_{\text {em }}=700 \mathrm{~nm}\right.$, Stokes shift $\left.\Delta \lambda_{\mathrm{St}}=15 \mathrm{~nm}\right)$.

Single crystal X-ray diffraction data ${ }^{[4]}$ show the formation of the "base-to-base" oriented dimers in the X-rayed crystal with the interbase distance of approximately $3.35 \AA$ caused by the cofacial $\pi$ - $\pi$-stacking interactions between the adjacent tetrapyrrolic fragments. The same type of supramolecular self-assembly is observed in polar aqueous solutions, while in pure DMF solution both of MPcs and the hybrid binuclear complexes 1-4 are monomeric. An addition of water to these solutions resulted in their dimerization with a substantial decrease in intensity of the characteristic absorption bands of the monomeric species with a simultaneous appearance of a new band near $650 \mathrm{~nm}$ which is hypsochromically shifted as compared with $Q$-band of initial monomeric species (Figure 2a). This suggests the formation of the $H$-type of dimeric species.

As it can be seen from data of the Table 1, the obtained monomer-to-aggregate ratios in aqueous solutions of the complexes 1-4 with DMF (1\% vol.) and those for their MPcs precursors are substantially different (Figure 2b). Hybrid iron(II)-centered complexes predominantly exist in the form of $H$-type dimers in polar media, while nickel(II)-centered complexes consist of equable amounts of monomeric and aggregated forms. The initial $\mathrm{Zr}\left(\mathrm{Cl}_{2}\right) \mathrm{Pc}$ and $\mathrm{Hf}\left(\mathrm{Cl}_{2}\right) \mathrm{Pc}$ in the same solutions exist mainly in monomeric forms.

A similar aggregation behavior of the above hybrid binuclear compounds has been observed in the polymer films produced from poly(vinylidene fluoride-co-hexafluoropropylene) copolymer (PVDF-HFP) (Table 1).

Polymer thin films $(\mathrm{d}=50 \mu \mathrm{m})$ were obtained by slow evaporation of the acetone PVDF-HFP solutions (10\% wt.) containing hybrid complexes 1-4 and initial MPcs in dry air. All of them exist predominantly in a monomolecular form in such polymer matrix with lowest monomerto-aggregate ratios in the case of the iron(II)-centered 

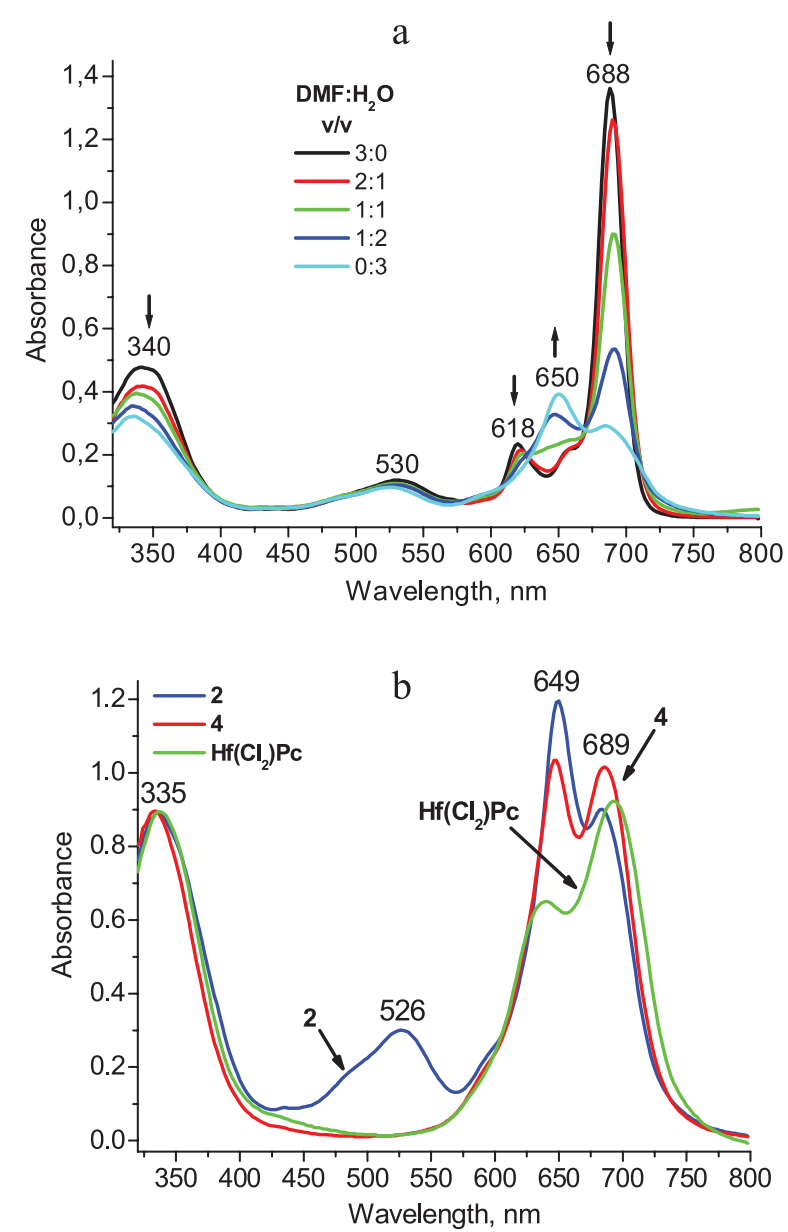

Figure 2. The UV-Vis spectra of the hybrid complexes 1-4 in DMF- $\mathrm{H}_{2} \mathrm{O}$ mixtures (a) and in aqueous solution with $1 \%$ vol. DMF (b).

Table 1. Monomer-to-aggregate ratios for the hybrid complexes 1-4 as well as initial MPcs in their aqueous solutions and in the PVDF-HFP polymeric films.

\begin{tabular}{ccccccc}
\hline $\mathrm{D}_{\text {mon }} / \mathrm{D}_{\text {aggr }}$ & $\mathbf{1}$ & $\mathbf{2}$ & $\mathbf{3}$ & $\mathbf{4}$ & $\mathrm{Hf}\left(\mathrm{Cl}_{2}\right) \mathrm{Pc}$ & $\mathrm{Zr}\left(\mathrm{Cl}_{2}\right) \mathrm{Pc}$ \\
\hline Solution & 0.83 & 0.75 & 0.97 & 0.98 & 1.39 & 1.62 \\
Polymer film & 1.27 & 1.42 & 2.30 & 1.85 & 3.79 & 2.4 \\
\hline
\end{tabular}

complexes and highest ones for the initial $\mathrm{Zr}\left(\mathrm{Cl}_{2}\right) \mathrm{Pc}$ and $\mathrm{Hf}\left(\mathrm{Cl}_{2}\right) \mathrm{Pc}$.

Because of the excellent thermal and chemical resistance, ferroelectric, piezoelectric and pyroelectric properties of PVDF-HFP matrix, ${ }^{[10,11]}$ these metal-containing composites seem to be prospective for the design of magnetic smart materials, as well as for the molecular electronics and sensing applications.

Thus, the UV-Vis spectra of the hybrid compounds 1-4 are rather similar in their monomolecular forms, while their aggregation degree in polar media is slightly affected by the nature of the central metal(II) ion. All the complexes under study form the $H$-type dimers both in their aqueous solutions and within the corresponding PVDF-HFP matrix. The polymer-immobilized hybrid complexes 1-4 exist in the systems described above, predominantly in their monomolecular forms and thus are promising smart materials for the various practical applications.

Acknowledgements. The authors wish to acknowledge Prof. V.V. Kochervinsky (Karpov Institute of Physical Chemistry) for providing PVDF-HFP experiments. The study of spectra in solutions was carried out at the expense of a subsidy allocated by ICP RAS for the effectuation of the State Task, theme 0082-2018-0006. The work was financially supported by RFBR (Grants No 16-32-00914 and No 18-03-00539).

\section{References}

1. Lukyanets E.A., Nemykin V.N. J. Porphyrins Phthalocyanines 2010, 14, 1-40.

2. Beletskaya I.P., Tyurin V.S., Tsivadze A.Yu., Guilard R., Stern C. Chem. Rev. 2009, 109(5), 1659-1713.

3. Tsivadze A.Yu. Russ. Chem. Rev. 2004, 73, 5-23.

4. Voloshin Y.Z., Varzatskii O.A., Korobko S.V., Chernii V.Y., Volkov S.V., Tomachynski L.A., Pehn'o V.I., Antipin M.S., Starikova Z.A. Inorg. Chem. 2005, 44, 822-824.

5. Sabin J.R., Varzatskii O.A., Voloshin Y.Z., Starikova Z.A., Novikov V.V., Nemykin V.N. Inorg. Chem. 2012, 51, 8362-8372.

6. Voloshin Y.Z., Varzatskii O.A., Tomilova L.G., Breusova M.O., Magdesieva T.V., Bubnov Yu.N., Kramer R. Polyhedron 2007, 26, 2733-2740.

7. Dudkin S.V., Erickson N.R., Vologzhanina A.V., Novikov V.V., Rhoda H.M., Holstrom C.D., Zatsikha Y.V., Yusubov M.S., Voloshin Y.Z., Nemykin V.N. Inorg. Chem. 2016, 55, 1186711882.

8. Voloshin Y., Belaya I., Kramer R. Cage Metal Complexes: Clathrochelates Revisited. Springer, 2017. 475 p.

9. Dudkin S.V., Belov A.S., Nelyubina Yu.V., Savchuk A.V., Pavlov A.A., Novikov V.V., Voloshin Y.Z. New J. Chem. 2017, 41, 3251-3259.

10. Ameduri B. Chem. Rev. 2009, 109, 6632-6686.

11. Prateek, Thakur V.K., Gupta R.K. Chem. Rev. 2016, 116, $4260-4317$. 